\title{
The Production of Alginate by Pseudomonas mendocina in Batch and Continuous Culture
}

\author{
By S. S. SENGHA, ${ }^{2 *}$ A. J. ANDERSON,${ }^{1}$ A. J. HACKING ${ }^{3}$ AND \\ E. A. DAWES ${ }^{1}$ \\ ${ }^{1}$ Department of Biochemistry, School of Life Sciences, University of Hull, Hull HU6 7RX, UK \\ ${ }^{2}$ The Nutrasweet Company, Mt Prospect, Illinois 60056, USA \\ ${ }^{3}$ Tate \& Lyle Group Research and Development, Philip Lyle Memorial Research Laboratory, \\ PO Box 68, Reading RG6 2BX, UK
}

(Received 19 September 1988; revised 29 November 1988; accepted 1 December 1988)

The effect of growth conditions on the production of alginate by highly mucoid strains of Pseudomonas mendocina was investigated, using $\mathrm{pH}$-controlled batch and continuous cultures. In batch culture, alginate was produced both during the exponential and stationary phases of growth. A polysaccharide concentration of $20 \mathrm{~g} \mathrm{l}^{-1}$ was obtained from medium containing glucose $\left(50 \mathrm{~g} \mathrm{l}^{-1}\right)$. In steady-state continuous culture under nitrogen limitation (dilution rate, $D=0.05 \mathrm{~h}^{-1}$ ), a similar alginate concentration was attained; more than $60 \%$ of the utilized glucose was converted to alginate and the polysaccharide concentration was ten-fold the biomass concentration. Increasing the dilution rate above $0 \cdot 1 \mathrm{~h}^{-1}$ decreased the proportion of glucose converted to alginate although the biomass was unchanged. The optimum dissolved oxygen tension (d.o.t.) for alginate production in nitrogen-limited continuous culture was approximately $40 \mathrm{~mm} \mathrm{Hg}(1 \mathrm{~mm} \mathrm{Hg}$ is approximately $133 \mathrm{~Pa})$. The respiration rate and bacterial density were independent of d.o.t. above $10 \mathrm{~mm} \mathrm{Hg}$. Under oxygen limitation, no alginate was produced but acetate was excreted into the culture fluid. Variants producing little alginate arose during growth in continuous culture. Under carbon limitation, alginate production was substantially decreased but not eliminated.

\section{INTRODUCTION}

The heteropolymer alginic acid is a linear glycuronan of (1,4)-linked $\beta$-D-mannuronic acid and its C-5 epimer $\alpha$-L-guluronic acid (Haug et al., 1966) that is synthesized by brown marine algae such as Ascophyllum nodosum (Lin \& Hassid, 1966a,b) and by several bacteria which include Azotobacter vinelandii (Gorin \& Spencer, 1966; Deavin et al., 1977), Pseudomonas aeruginosa (Evans \& Linker, 1973), Pseudomonas mendocina (Govan et al., 1981; Hacking et al., 1983), Pseudomonas putida and Pseudomonas fluorescens (Govan et al., 1981). Bacterial alginate differs from its algal counterpart in being $O$-acetylated to a variable degree. Acetylation is associated with only mannuronic acid residues (Davidson et al., 1977; Skjak-Braek et al., 1986) and the degree of acetylation depends on the growth conditions of the bacteria (Linker \& Jones, 1966; Evans \& Linker, 1973). Skjak-Braek et al. (1985) suggested that in $A$. vinelandii, intracellular acetylation of alginate determines the subsequent extracellular epimerization of mannuronic to guluronic acid and hence determines physical properties such as ion binding and gel formation. The calcium-dependent epimerase is thought to act on the preformed mannuronan chain by a multiple attack mechanism (Larsen et al., 1986) and the composition of the polymer produced is influenced by the $\mathrm{Ca}^{2+}$ concentration (Annison \& Couperwhite, 1986a). Alginates from Pseudomonas species are devoid of the polyguluronic acid sequences found in the polymer from

Abbreviation: d.o.t., dissolved oxygen tension. 
A. vinelandii (Sherbrock-Cox et al., 1984; Skjak-Braek et al., 1986). The absence of a calciumdependent C-5 epimerase from mucoid strains of $P$. aeruginosa (Singh et al., 1987) implies that the biosynthesis of alginate differs from that in $A$. vinelandii and offers an explanation for the independence of the mannuronic to guluronic acid ratio to the $\mathrm{Ca}^{2+}$ concentration (Dunne \& Buckmire, 1985) in Pseudomonas species.

The pathways of alginate biosynthesis in bacteria have been investigated (Pindar \& Bucke, 1975; Piggott et al., 1981 ; Banerjee et al., 1983; Anderson et al., 1987) and recently, much work (reviewed by Deretic et al., 1987) has been done to establish gene function and regulation in $P$. aeruginosa. Less is known about the influence of growth conditions on alginate production but these factors are important in relation to the potential commercial application of bacterial alginate as an alternative to algal alginate. It may be possible to produce polymers possessing suitable rheological properties for particular applications: for example, the proportions of mannuronic and guluronic acids could probably be controlled by the choice of growth conditions employed.

Alginate can be synthesized from sucrose by $A$. vinelandii NCIB 9068 in continuous culture under a range of nutrient limitations (Deavin et al., 1977; Jarman et al., 1978). The highest rates of alginate production were recorded with molybdate or phosphate as the growth-limiting substrate but a substantial rate of synthesis was observed even under carbon limitation. High yields of alginate have been obtained in nitrogen-limited continuous culture, with glucose as the carbon source, for both $P$. aeruginosa (Mian et al., 1978) and $P$. mendocina (Hacking et al., 1983).

The effect of dilution rate $(D)$ on the steary-state concentrations of alginate and biomass has not been extensively studied. Phosphate-limited cultures of $\boldsymbol{A}$. vinelandii produced substantially greater concentrations of alginate and biomass at low dilution rates (Deavin et al., 1977), the rate of alginate synthesis being independent of growth rate over the range $D=0.05-0.25 \mathrm{~h}^{-1}$. Similar results were obtained by Annison \& Couperwhite (1986b). In contrast, in nitrogenlimited continuous cultures of $P$. aeruginosa, alginate and biomass concentrations were unchanged over the range $D=0.05-0 \cdot 1 \mathrm{~h}^{-1}$ (Mian et al., 1978). Likewise, there was little change in the biomass or alginate concentrations in nitrogen-limited cultures of $P$. mendocina over the range $D=0.03-0.06 \mathrm{~h}^{-1}$ (Hacking et al., 1983).

The dissolved oxygen tension (d.o.t.) is critical for alginate production by $A$. vinelandii (Jarman et al., 1978; Annison \& Couperwhite, 1986b). At low d.o.t., the organism accumulates the intracellular storage compound poly- $\beta$-hydroxybutyrate whereas, at high d.o.t., the onset of respiratory protection results in very high respiration rates; consequently, efficient conversion of the carbon source to alginate in continuous culture is achieved only if the d.o.t. is accurately controlled. The effect of d.o.t. on alginate production by Pseudomonas species appears to be less critical and a value of approximately $20 \%$ air saturation has been employed in studies using $P$. aeruginosa (Mian et al., 1978) and P. mendocina (Hacking et al., 1983).

In this paper we examine the effects of growth conditions, including nutrient limitation, growth rate and d.o.t. on alginate production by strains of $P$. mendocina that have previously been selected (Hacking et al., 1983) for their improved stability and enhanced ability to produce alginate.

\section{METHODS}

Growth and maintenance of organisms. Lyophilized cultures of Pseudomonas mendocina U1 (NCIB 11687), NCIB 10541 (wild-type) and muc18 (Tate and Lyle) were stored at $-20^{\circ} \mathrm{C}$. Shake-flask cultures were grown in a mineral salts medium (Jayasuriya, 1955) supplemented with carbon source $\left(20 \mathrm{~g} \mathrm{l}^{-1}\right)$ and adjusted to a $\mathrm{pH}$ value of 7·2. A complex medium which contained ( $\mathrm{g}^{-1}$ ) glucose (10), peptone (5), yeast extract (3), and malt extract (3), was also used. The medium of Anderson et al. (1987) was used for nitrogen-limited continuous cultures; for carbon-limited growth the glucose and $\left(\mathrm{NH}_{4}\right)_{2} \mathrm{HPO}_{4}$ concentrations were adjusted to $10 \mathrm{~g} \mathrm{l}^{-1}$ and $3 \mathrm{~g} \mathrm{l}^{-1}$, respectively.

Continuous culture. Bacteria were grown at $30^{\circ} \mathrm{C}$ in a vortex-type chemostat with a working volume of 1.751 . The $\mathrm{pH}$ was maintained at $7 \cdot 0 \pm 0 \cdot 1$ by automatic addition of $\mathrm{KOH}(2 \mathrm{M})$, foaming was controlled by periodic small additions of antifoam (6560 defoamer, Bevaloid Chemicals) and the culture was stirred (1240 r.p.m.) with a vaneddisc impeller. The d.o.t. was measured with a galvanic oxygen electrode and controlled to the required value by alteration of the proportions of nitrogen and oxygen in the inflowing gas (total flow rate: $600 \mathrm{ml} \mathrm{min}^{-1}$ ). The gas flow into and out of the chemostat was measured by rotary gas meters (Lange). The oxygen concentration in the 
effluent gas was measured with a paramagnetic analyser (type OA 137, Servomex Controls) and the carbon dioxide concentration was determined with an infrared analyser (model 613, Analytical Development Co.). Chemostat inocula were shake-flask cultures in glucose medium prepared from a single mucoid colony. The chemostat was considered to be in steady-state when measured parameters (including biomass, alginate, glucose and ammonia concentrations and the effluent gas composition) were constant for at least three residence times.

The proportion of non-mucoid variants was monitored by plating on solidified complex medium; the data presented refer to cultures containing less than $5 \%$ non-mucoid organisms at the time of sampling.

For $\mathrm{pH}$-controlled batch cultures the medium composition and growth conditions were as described for nitrogen-limited cultures except that air $\left(600 \mathrm{ml} \mathrm{min}^{-1}\right)$ was used to maintain the d.o.t. above $100 \mathrm{~mm} \mathrm{Hg}(1 \mathrm{~mm}$ $\mathrm{Hg}$ is approximately $133 \mathrm{~Pa}$ ) throughout the experiment.

Biomass concentration. For non-viscous cultures, samples $(2 \times 20 \mathrm{ml})$ were centrifuged $(34000 \mathrm{~g}, 15 \mathrm{~min})$ at $20^{\circ} \mathrm{C}$. The bacteria were resuspended in water $(30 \mathrm{ml})$ and centrifuged as before. The washed bacteria were then transferred quantitatively to preweighed vials and dried $\left(90^{\circ} \mathrm{C}\right)$ to a constant weight. For viscous cultures the separation of alginate and bacteria was facilitated by treatment with EDTA and $\mathrm{NaCl}$ prior to washing, as described by Hacking et al. (1983).

Purification of alginate. Crude alginate, isolated from culture fluid by precipitation with propan-2-ol, was purified by repeated dissolution in water followed by re-precipitation (four times) with propan-2-ol and drying of the product at $37^{\circ} \mathrm{C}$. Purified alginate contained no detectable nucleic acid and less than $0 \cdot 1 \%(w / w)$ protein, as compared with approximately $1 \%(w / w)$ protein that was present in unpurified alginate. This material was used for analytical and rheological studies.

Infra-red spectroscopy. $\mathrm{KBr}$ discs were prepared and spectra were recorded using a Perkin-Elmer 457 instrument. The proportion of mannuronic and guluronic acids was estimated by the method of Fillipov \& Kohn (1974).

Gas-liquid chromatography. The concentration of acetic acid in samples of culture supernatant solution was determined by chromatography on a column $(2.5 \mathrm{~mm} \times 1.9 \mathrm{~m})$ of Porapak QS in a Philips PV4000 instrument with a flame-ionization detector. The oven temperature was $210^{\circ} \mathrm{C}$ and the flow rate of the carrier gas (nitrogen) was $35 \mathrm{ml} \mathrm{min}{ }^{-1}$. Samples of supernatant fluid $(4.5 \mathrm{ml})$ were acidified with $\mathrm{H}_{2} \mathrm{SO}_{4}(2 \mathrm{M}, 0.5 \mathrm{ml})$ containing propionic acid as an internal standard. The solution was then extracted with an equal volume of diethyl ether, centrifuged to break the emulsion and the ether layer retained for analysis. Standard mixtures containing both acetic and propionic acids were used for calibration.

Analytical procedures. Glucose was estimated by the glucose oxidase method, using a commercial kit (GODPERID: Boehringer). Ammonia was determined by the procedure of Chaney \& Marbach (1962).

Alginate determination. Alginate was determined gravimetrically and by uronic acid analysis, as described by Anderson et al. (1987).

Acetate ester content of alginate. The method of McComb \& McCready (1957) was used with $\beta$-D-glucose pentaacetate as a standard.

\section{RESULTS}

\section{General physiology}

When cultured on complex medium solidified with agar, colonies of alginate-overproducing strains became covered by copious amounts of alginate, resulting in a raised and mucoid appearance, in contrast to the small smooth colonies produced by the parental strain (NCIB 10541). Chemostat-grown bacteria that had lost their ability to overproduce alginate reverted to the parental colony type on complex medium. Cultivation of all three strains on minimal medium yielded smaller colonies and the mucoid appearance of alginate overproducers was evident only with mannose, glucose or fructose as carbon sources.

In shake-flasks, complex medium or minimal medium supplemented with glucose, fructose or mannose produced viscous cultures from which alginate was readily precipitated. Growth on gluconate did not yield viscous cultures but alginate could be precipitated.

After negative staining of the samples with phosphotungstic acid, they were studied using transmission electron microscopy. Bacteria grown on solid complex medium showed the presence of a densely stained outer layer; this staining was virtually absent from bacteria grown in shake-flasks. 


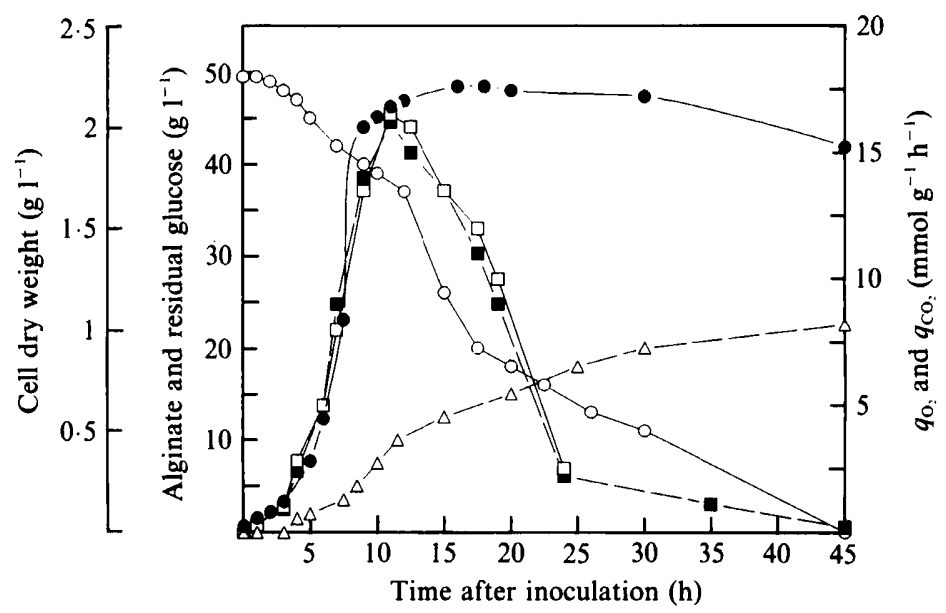

Fig. 1. Time course of alginate biosynthesis by batch-grown $P$. mendocina U1. The organism was grown in the nitrogen-limited batch medium with glucose as carbon source at $\mathrm{pH} 7 \cdot 0,0.61$ air $\mathrm{min}^{-1}, 30^{\circ} \mathrm{C}$ and 1240 r.p.m. Cell dry weight $(\bigcirc)$, alginate $(\triangle)$, glucose $(O), q_{\mathrm{O}_{2}}(\square)$ and $q_{\mathrm{CO}_{2}}(\square)$ were determined as described in Methods.

Table 1. Alginate production by Pseudomonas mendocina grown under various limitations

Culture d.o.t. was maintained at $\mathbf{4 0} \pm 2 \mathrm{~mm} \mathrm{Hg}$; for oxygen-limited cultures the d.o.t. was undetectable. \pm Values correspond to standard deviations from the mean for at least five separate determinations. The dilution rate was $0.05 \pm 0.003 \mathrm{~h}^{-1}$ in all cases.

\begin{tabular}{|c|c|c|c|c|c|c|c|}
\hline Strain & $\begin{array}{l}\text { Growth } \\
\text { limitation }\end{array}$ & $\begin{array}{l}\text { Cell dry wt } \\
\left(\mathrm{g}^{-1}\right)\end{array}$ & $\begin{array}{c}\text { Alginate } \\
\left(\mathrm{g}^{-1}\right)\end{array}$ & $\begin{array}{c}\text { Acetate } \\
\left(\mathrm{g} \mathrm{I}^{-1}\right)\end{array}$ & $\begin{array}{l}\text { Glucose } \\
\text { consumed } \\
\left(\mathrm{g} \mathrm{l}^{-1}\right)\end{array}$ & $\begin{array}{l}\text { Conversion of } \\
\text { glucose into } \\
\text { alginate } \\
(\%, w / w)\end{array}$ & $\begin{array}{c}\text { Conversion of } \\
\text { glucose into } \\
\text { acetate } \\
(\%, w / w)\end{array}$ \\
\hline Parent & $\begin{array}{l}\mathbf{N} \\
\mathbf{C} \\
\mathbf{O}\end{array}$ & $\begin{array}{l}2.10 \pm 0.15 \\
2.82 \pm 0.15 \\
1.23 \pm 0.17\end{array}$ & $\begin{array}{l}2.5 \pm 0.5 \\
2.1 \pm 0.45 \\
\quad \text { ND }\end{array}$ & $\begin{array}{c}\text { ND } \\
\text { ND } \\
0.38 \pm 0.03\end{array}$ & $\begin{array}{l}12.5 \pm 1.3 \\
15.0 \pm 0.6 \\
3.50 \pm 0.35\end{array}$ & $\begin{array}{l}20 \cdot 0 \\
14 \cdot 0 \\
\text { NA }\end{array}$ & $\begin{array}{l}\text { NA } \\
\text { NA } \\
9 \cdot 0\end{array}$ \\
\hline U1 & $\begin{array}{l}\mathrm{N} \\
\mathrm{C} \\
\mathrm{O}\end{array}$ & $\begin{array}{l}2.01 \pm 0.11 \\
2.11 \pm 0.13 \\
1.37 \pm 0.13\end{array}$ & $\begin{array}{c}23.5 \pm 2.0 \\
3.7 \pm 0.6 \\
\text { ND }\end{array}$ & $\begin{array}{c}\text { ND } \\
\text { ND } \\
0.52 \pm 0.11\end{array}$ & $\begin{array}{cl}36.3 & \pm 1.1 \\
15.6 & \pm 1.3 \\
3.85 & \pm 0.63\end{array}$ & $\begin{array}{c}64 \cdot 0 \\
23 \cdot 7 \\
\text { NA }\end{array}$ & $\begin{array}{c}\mathrm{NA} \\
\mathrm{NA} \\
13 \cdot 0\end{array}$ \\
\hline muc18 & $\begin{array}{l}\mathrm{N} \\
\mathrm{C} \\
\mathrm{O}\end{array}$ & $\begin{array}{l}1.94 \pm 0.13 \\
2.18 \pm 0.17 \\
1.18 \pm 0.14\end{array}$ & $\begin{aligned} & 21.5 \pm 2.0 \\
& 2.7 \pm 0.5 \\
& \text { ND }\end{aligned}$ & $\begin{array}{c}\text { ND } \\
\text { ND } \\
0.67+0.09\end{array}$ & $\begin{array}{c}34.0 \pm 1.5 \\
15.2 \pm 1.35 \\
3.63 \pm 0.64\end{array}$ & $\begin{array}{l}63.0 \\
17.8 \\
\text { NA }\end{array}$ & $\begin{array}{c}\text { NA } \\
\text { NA } \\
21 \cdot 0\end{array}$ \\
\hline
\end{tabular}

ND, Not detected; NA, not applicable.

\section{Growth in a pH-controlled batch fermenter}

When the growth of $P$. mendocina $\mathrm{U} 1$ was restricted by the availability of nitrogen, alginate was produced during the exponential phase of growth. However, most $(75 \%)$ of the polymer was produced after exhaustion of the nitrogen source and consequent cessation of growth (Fig. 1). Alginate production continued at a gradually decreasing rate until no glucose remained. Peak values for $q_{\mathrm{CO}_{2}}$ and $q_{\mathrm{O}_{2}}$ of 16.5 and $15.0 \mathrm{mmol} \mathrm{g}^{-1} \mathrm{~h}^{-1}$, respectively, were attained some time (approximately one generation time) after the exhaustion of the nitrogen source. From an initial glucose concentration of $50 \mathrm{~g} \mathrm{l}^{-1}$, a final concentration of $20 \mathrm{~g}$ alginate $1^{-1}$ was routinely obtained. The average conversion efficiency of glucose into alginate for several experiments was $47.5 \%(\mathrm{w} / \mathrm{w})$ and an average of $11.5 \mathrm{~g}$ alginate $\left(\mathrm{g}\right.$ bacteria) ${ }^{-1}$ was obtained.

Average maximum specific growth rates $\left(\mu_{\max }\right)$ or 0.40 and $0.43 \mathrm{~h}^{-1}$ were calculated for the mucoid strains U1 and muc18, respectively; a slightly higher $\mu_{\max }$ of $0.46 \mathrm{~h}^{-1}$ was obtained with the parental strain. 


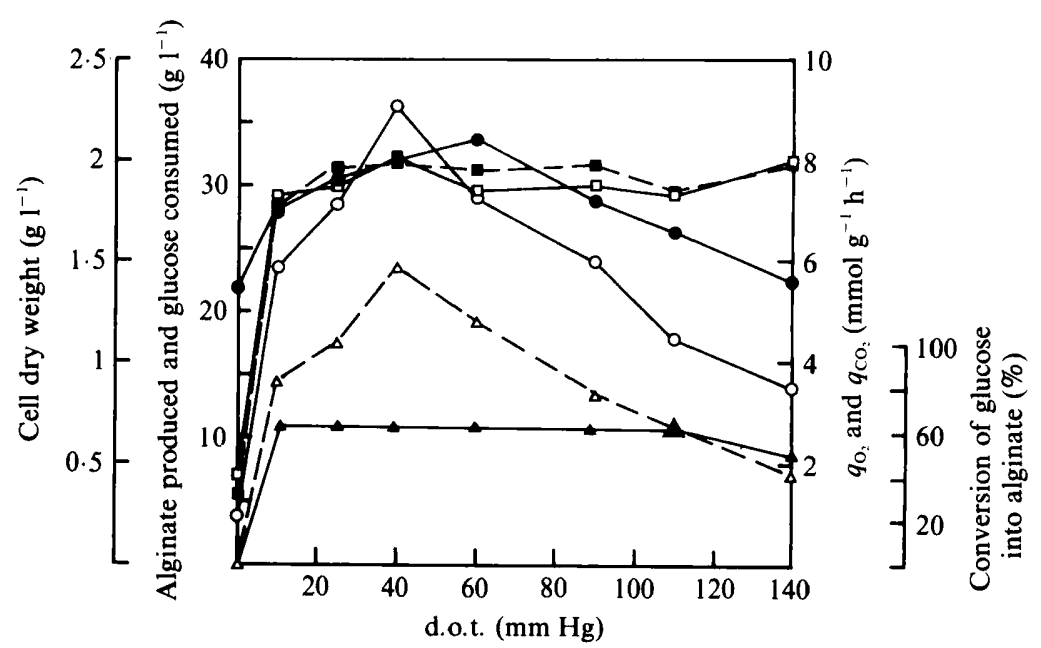

Fig. 2. Effect of culture d.o.t. on growth and alginate production by $P$. mendocina $U 1$ in continuous culture. The organism was grown in the nitrogen-limiting medium containing glucose $\left(50 \mathrm{~g}^{-1}\right)$ at $D=0.05 \pm 0.002 \mathrm{~h}^{-1}$. Cell dry weight $(O)$, alginate $(\triangle)$, glucose $(\mathrm{O}), q_{\mathrm{O}_{2}}(\square), q_{\mathrm{CO}_{2}}(\square)$ and percentage conversion of glucose into alginate $(\boldsymbol{\Lambda})$ were determined as described in Methods.

\section{Continuous cultivation}

Nitrogen-limited growth. Alginate over-producing strains synthesized alginate at high specific rates, the maximum being $0.82 \mathrm{~g}$ (g cells) $)^{-1} \mathrm{~h}^{-1}$ for strain Ul at $D=0.05 \mathrm{~h}^{-1}$. The parental strain also produced alginate, albeit at the low rate of $0.09 \mathrm{~g}(\mathrm{~g} \text { cells })^{-1} \mathrm{~h}^{-1}$. The highest yield of alginate from glucose was approximately $64 \%\left[11.7 \mathrm{~g}\right.$ alginate $\left.(\mathrm{g} \text { bacteria })^{-1}\right]$ and the lowest was $20 \%(w / w)$ (Table 1). Various parameters for three of the strains used are presented in Table 1. Nitrogen-limited cultures of mucoid strains were non-viscous, despite the high alginate concentration present.

Although chemostat inocula contained only mucoid organisms, as judged by the uniform appearance of colonies on solidified media, non-mucoid variants producing little alginate became detectable after approximately ten generation times. As the proportion of non-mucoid variants increased, there were concomitant decreases in the glucose consumption rate and alginate concentration.

Carbon-limited growth. Similar amounts of alginate were synthesized by the parental and mucoid strains of $P$. mendocina when growth was limited by the availability of glucose (Table 1 ). Although the ratio of alginate to cells for the mucoid strains was approximately 1.5 , compared with 11 for nitrogen-limited growth, the percentage conversion of glucose into alginate was less dramatically affected.

Oxygen-limited growth. Oxygen limitation of growth was imposed on a nitrogen-limited culture by decreasing the partial pressure of oxygen in the gas supply to the chemostat until the cell density was approximately $50-70 \%$ of that for the original steady-state culture. This decrease in cell density was accompanied by the appearance of $\mathrm{NH}_{4}^{+}$and acetate in the culture supernatant (Table 1). Oxygen-limited cultures produced no detectable alginate and were of a light reddish-brown colour, as compared with the light yellow-green colour of both nitrogen- and carbon-limited cultures. This colour was associated with the bacteria and was absent from the culture fluid. The colour change began about $30 \mathrm{~min}$ after changing the growth limitation from nitrogen to oxygen and could be reversed by restoration of nitrogen limitation.

Effect of dissolved oxygen tension on alginate production. Alginate was detectable in culture fluid at all d.o.t. values above $10 \mathrm{~mm} \mathrm{Hg}$; the conversion of glucose into alginate was relatively constant up to a d.o.t. of $112 \mathrm{~mm} \mathrm{Hg}$ (Fig. 2). The highest alginate concentration was achieved 


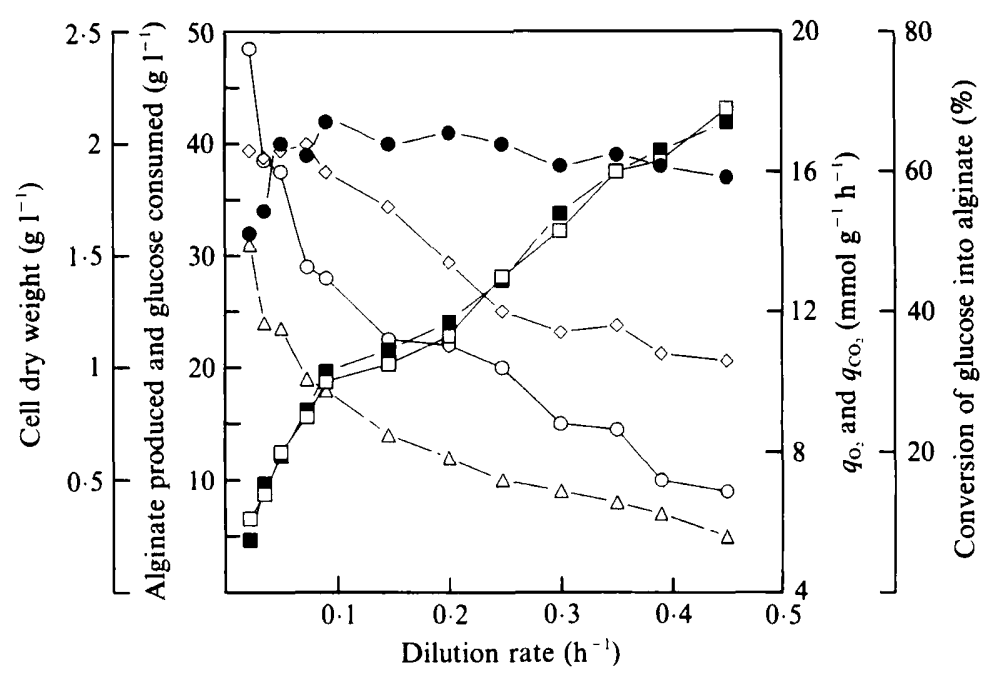

Fig. 3. Effect of dilution rate on growth and alginate production by $P$. mendocina U1. The organism was grown in the nitrogen-limiting medium containing glucose $\left(50 \mathrm{~g} \mathrm{l}^{-1}\right)$. The culture d.o.t. was maintained at $5.32 \pm 0.266 \mathrm{kPa}$. Cell dry weight $(\bigcirc)$, alginate $(\triangle)$, glucose $(O), q_{\mathrm{O}_{2}}(\square), q_{\mathrm{CO}_{2}}(\square)$ and conversion of glucose into alginate $(\diamond)$ were determined as described in Methods.

at a d.o.t. of $40 \mathrm{~mm} \mathrm{Hg}$ and in situ $q_{\mathrm{O}_{2}}$ and $q_{\mathrm{CO}_{2}}$ values reached a plateau at d.o.t. values of $20 \mathrm{~mm} \mathrm{Hg}$ and above.

Effect of dilution rate on alginate production. The alginate concentration in the culture supernatant was markedly affected by $D$ and decreased from a maxiumum value of $31.0 \mathrm{~g}^{-1}$ to $6.5 \mathrm{~g}^{-1}$ when $D$ was increased over 19 -fold (Fig. 3). The amount of glucose converted into alginate was relatively constant up to $D=0.14 \mathrm{~h}^{-1}$ and then decreased gradually, following the trends in alginate concentration and glucose consumption. The cell density was largely independent of $D$ above $0.05 \mathrm{~h}^{-1}$, but both the $q_{\mathrm{O}_{2}}$ and $q_{\mathrm{CO}_{2}}$ values increased at similar rates as $D$ was increased.

Stability of mucoid strains in continuous culture. Non-mucoid variants arose under all growth conditions (results not shown) but most rapidly in oxygen-limited cultures of strain U1, despite the fact that no alginate was produced under oxygen limitation.

\section{Properties of alginate}

Propan-2-ol treatment of the non-viscous supernatant fluid from stirred batch or continuous cultures invariably yielded a granular white precipitate, in contrast to the stringy gel obtained with supernatant from (viscous) shake-flask cultures. Rheological and electrophoretic analyses (not shown) of alginate isolated from both continuous and $\mathrm{pH}$-controlled batch cultures indicated a highly-degraded low-molecular-mass product, similar to low-grade commercial alginates. At low concentrations $\left(<3 \mathrm{~g} \mathrm{l}^{-1}\right)$, precipitation with propan-2-ol gave incomplete recovery and more reliable quantification was obtained by uronic acid analysis. Unpurified alginate, recovered from continuous cultures by a single precipitation with propan-2-ol, did not yield viscous solutions, even at a concentration of $60 \mathrm{~g} \mathrm{l}^{-1}$. In contrast, the product isolated from glucose-grown shake-flask cultures produced a viscous solution at a concentration of $2 \mathrm{~g} \mathrm{l}^{-1}$. This latter type of alginate readily gelled upon addition of $2 \mathrm{M}-\mathrm{CaCl}_{2}$ and formed a flocculent white precipitate characteristic of alginate, when added to $50 \mathrm{~mm}-\mathrm{H}_{2} \mathrm{SO}_{4}$.

Infrared spectra of $P$. mendocina alginate were very similar to those obtained for algal alginate, except that additional absorbance bands $\left(1725\right.$ and $\left.1230 \mathrm{~cm}^{-1}\right)$, due to the presence of $O$-acetyl residues, were seen in the bacterial alginates. From the ratio of the absorbance values at 
Table 2. Mannuronic to guluronic acid ratio of various alginates

Bacteria were grown in continuous culture at a $D$ of $0.05 \mathrm{~h}^{-1}$.

\section{Origin of sample}

P. mendocina U1 (N-limitation)

P. mendocina Ul (C-limitation)

$P$. mendocina muc18 (N-limitation)

$P$. mendocina U1 (N-limitation)*

A. vinelandii SM52B (N-limitation)*

Algal alginate (BDH)
Ratio of mannuronic

to guluronic acid

$4 \cdot 0$

0.67

$2 \cdot 45$

$1 \cdot 70$

1.70

1.08

* Samples of lyophilized bacteria were provided by Tate \& Lyle.

Table 3. Acetate ester content of various alginate samples

\begin{tabular}{|c|c|c|c|}
\hline Strain & $\begin{array}{l}\text { Growth } \\
\text { conditions }\end{array}$ & $\begin{array}{c}D \\
\left(\mathrm{~h}^{-1}\right)\end{array}$ & $\begin{array}{c}\text { Acetate ester } \\
\text { content } \\
(\%, w / w)\end{array}$ \\
\hline $\begin{array}{l}\text { P. mendocina mucl } 8 \\
\text { P. mendocina } 10541 \\
P . \text { mendocina } \mathrm{U} 1 \\
\text { Algal alginate }(\mathrm{BDH})\end{array}$ & $\begin{array}{l}\text { Solidified } \\
\text { complex medium } \\
\text { NA }\end{array}$ & $\begin{array}{l}\text { NA } \\
\text { NA } \\
\text { NA } \\
\text { NA }\end{array}$ & $\begin{array}{l}1 \cdot 44 \\
0.63 \\
2 \cdot 22 \\
0\end{array}$ \\
\hline $\begin{array}{l}\text { P. mendocina muc } 18 \\
\text { P. mendocina } \mathrm{U} 1\end{array}$ & C-limitation & $\begin{array}{l}0.05 \\
0.05\end{array}$ & $\begin{array}{l}0 \\
1.20\end{array}$ \\
\hline $\begin{array}{l}P . \text { mendocina } \mathrm{U} 1 \\
P . \text { mendocina } \mathrm{U} 1 \\
P . \text { mendocina } \mathrm{U} 1 \\
P . \text { mendocina } \mathrm{U} 1 \\
P . \text { mendocina muc18 } \\
\text { A. vinelandii } \mathrm{SM} 52 \mathrm{~B}^{*}\end{array}$ & $\mathbf{N}$-limitation & $\begin{array}{l}0.02 \\
0 \cdot 14 \\
0.25 \\
0.44 \\
0.05 \\
0.05\end{array}$ & $\begin{array}{r}0.99 \\
1.70 \\
0.95 \\
3.35 \\
1.64 \\
12.50\end{array}$ \\
\hline
\end{tabular}

$1125 / 1030 \mathrm{~cm}^{-1}$ (Fillipov \& Kohn, 1974), the mannuronic to guluronic acid ratio was estimated for various samples (Table 2). In common with other bacterial alginates, $O$-acetylation was present to a varying degree (Table 3) but there was no clear pattern relating the degree of acetylation to the strain or growth conditions.

The natural abundance ${ }^{13} \mathrm{C}-\mathrm{NMR}$ spectrum (not shown) of purified polymer, isolated from the supernatant of nitrogen-limited continuous cultures, was similar to that of algal alginate and there was no indication of significant contamination by other components.

\section{DISCUSSION}

As found with alginate-producing strains of $P$. aeruginosa (Doggett et al., 1966; Evans \& Linker, 1973), the exopolysaccharide of $P$. mendocina was loosely associated with the cell. Purified alginate appeared to be free of major contamination, as judged by spectroscopic and chemical analyses.

P. mendocina synthesized alginate principally during the late exponential and early stationary phases of growth. The rate of alginate synthesis did not increase after cessation of growth. Similar kinetics have been reported for production of alginate by $A$. vinelandii (Horan et al., 1981) and for the synthesis of a galactoglucan by Pseudomonas NCIB 11264 (Williams \& Wimpenny, 1977). In contrast, batch cultures of $A$. vinelandii (Deavin et al., 1977) and $P$. 
aeruginosa (Annison \& Couperwhite, 1987) produced alginate only during exponential growth. It is difficult to rationalize these observations in the absence of detailed studies of the effect of growth conditions on the production of alginate in batch culture.

In continuous culture under nitrogen-limitation, the alginate concentration decreased substantially with increasing growth rate, from over $30 \mathrm{~g} \mathrm{l}^{-1}$ at $D=0.023 \mathrm{~h}^{-1}$ to $10 \mathrm{~g} \mathrm{l}^{-1}$ at $D=$ $0.30 \mathrm{~h}^{-1}$ (Fig. 3). A dilution rate of $0.05 \mathrm{~h}^{-1}$ was chosen for further studies to provide a compromise between polymer yield and productivity.

The efficiency of conversion of glucose to alginate was constant between d.o.t. values of 10 and $112 \mathrm{~mm} \mathrm{Hg}$; this contrasts greatly with the behaviour of $A$. vinelandii where the conversion efficiency falls dramatically above a d.o.t. of $4 \mathrm{~mm} \mathrm{Hg}$ (Horan et al., 1983). However, such a difference is not surprising because of the involvement of 'respiratory protection' in Azotobacter species (Dalton \& Postgate, 1969). This represents a significant advantage of Pseudomonas species for commercial alginate production since it is difficult to control the d.o.t. in large fermenters. The absence of alginate synthesis in oxygen-limited chemostat culture implies that this condition must also be avoided in batch culture if maximum polymer yield is to be achieved. In shake-flask cultures the peak oxygen demand during the late exponential phase of growth, coupled with the effect of viscosity on aeration of the culture, is likely to induce oxygenlimitation and hence depress alginate yield.

Under carbon-limitation, a smaller amount of alginate was produced. Since the biomass and polymer concentration in cultures were similar, a significant proportion of the total available carbon is converted to alginate at the expense of growth by both the mucoid and parental strains under these conditions. Substantial alginate synthesis during carbon-limited growth has been observed with $A$. vinelandii (Deavin et al., 1977) and $P$. aeruginosa (Mian et al., 1978).

The appearance of non-mucoid variants in continuous cultures has previously been described for $A$. vinelandii (Horan et al., 1983), $P$. aeruginosa (Govan, 1975; Mian et al., 1978) and $P$. mendocina (Hacking et al., 1983). The instability of strains producing alginate and other exopolysaccharides is well known, but further insight into this problem is needed before stable strains can be provided for industrial application.

The production of a low-molecular-mass polymer in continuous and stirred batch cultures is almost certainly due to the alginate lyase activity of $P$. mendocina, as reported by Hacking et al. (1983). These workers overcame this problem by incorporating a commercial Bacillus proteolytic preparation in culture media to inactivate the lyase. The specific activity of alginate lyase and the concentration of unsaturated uronic acids, characteristic of degradation, was significantly greater in fermenter cultures than in shake-flask glucose cultures (A. J. Anderson, unpublished) and this is in accordance with the suggestion (Horan et al., 1983) that mechanical damage allows leakage of intracellular lyase in fermenter cultures. From the results shown in Table 2, it is clear that alginate from nitrogen-limited cultures contains a higher proportion of mannuronate than guluronate residues. The converse was true for alginate from carbon-limited cultures. The degree of acetylation of alginate from $P$. mendocina was substantially less than in $A$. vinelandii.

Our work shows that efficient conversion of glucose to alginate can be effected under appropriate growth conditions in both batch and continuous culture. A similar conversion efficiency has been reported for batch cultures of $A$. vinelandii (Chen et al., 1985) with sucrose as the carbon source but the product concentration was only a third of that achieved in the present study due to the lower substrate concentration employed. The inherent instability of alginateproducing strains in continuous culture, found in this and other studies, suggests that only batch culture would be practical for commercial production of bacterial alginate. Studies on the mechanism of gene regulation may eventually provide the key to obtaining stable alginateproducing strains for commercial use. Although the quality of $P$. mendocina alginate can be enhanced by inclusion of a protease in the culture medium (Hacking et al., 1983) to minimize degradation, it would be preferable to eliminate lyase activity, which is closely related to the $\mathrm{C}-5$ epimerase found in alginate-producing strains of $A$. vinelandii (Gacesa, 1987).

Alternative pathways exist for alginate biosynthesis in $P$. mendocina and $A$. vinelandii (Anderson et al., 1987). In shake-flask cultures of these organisms, alginate synthesis from 
glucose occurs predominantly via a degradative route involving the Entner-Doudoroff pathway, rather than directly from undegraded $\mathrm{C}_{6}$ units. The relative importance of the pathways under conditions of maximum productivity has not been investigated but would be of interest in relation to the efficiency of bacterial alginate biosynthesis.

\section{REFERENCES}

Anderson, A. J., Hacking, A. J. \& Dawes, E. A. (1987). Alternative pathways for the biosynthesis of alginate from fructose and glucose in Pseudomonas mendocina and Azotobacter vinelandii. Journal of General Microbiology 133, 1045-1052.

ANNISON, G. \& COUPER WHITE, I. (1986a). Influence of calcium on alginate production and composition in continuous cultures of Azotobacter vinelandii. Applied Microbiology and Biotechnology 25, 55-61.

ANNISON, G. \& COUPERWHITE, I. $(1986 b)$. Effect of limiting substrate concentration, growth rate and aeration on alginate composition and production by Azotobacter vinelandii in continuous culture. Food Hydrocolloids 1, 101-111.

ANNISON, G. \& Couperwhite, I. (1987). Composition of alginate synthesized during the growth cycle of Pseudomonas aeruginosa. Australian Journal of Biological Sciences 40, 435-441.

Banerjee, P. C., Vanags, R. I., Chakrabarty, A. M. \& MaITRA, P. K. (1983). Alginic acid synthesis in Pseudomonas aeruginosa mutants defective in carbohydrate metabolism. Journal of Bacteriology 155, 238-245.

Chaney, A. L. \& Marbach, E. P. (1962). Modified reagents for determination of urea and ammonia. Clinical Chemistry 8, 130-133.

Chen, W.-P., Chen, J.-Y., Chang, S.-C. \& Su, C.-L. (1985). Bacterial alginate produced by a mutant of Azotobacter vinelandii. Applied and Environmental Microbiology 49, 543-546.

Dalton, H. \& Postgate, J. R. (1969). Effect of oxygen on the growth of Azotobacter chroococcum in batch and continuous culture. Journal of General Microbiology 54, 463-473.

Davidson, I. W., Sutherland, I. W. \& Lawson, C. J. (1977). Localization of $O$-acetyl groups of bacterial alginate. Journal of General Microbiology 98, 603606.

Deavin, L., Jarman, T. R., Lawson, C. J., Righelato, R. C. \& Slocombe, S. (1977). The production of alginic acid by Azotobacter vinelandii. In Extracellular Microbial Polysaccharides, pp. 14-26. Edited by P. A. Sandford \& A. Laskin. Washington DC: American Chemical Society.

Deretic, V., Gill, J. F. \& Chakrabarty, A. M. (1987). Alginate biosynthesis: a model system for gene regulation and function in Pseudomonas. Bio/Technology 5, 469-477.

Doggett, R. G., Harrison, G. M., Stillwell, R. N. \& Wallis, E. S. (1966). An atypical Pseudomonas aeruginosa associated with cystic fibrosis of the pancreas. Journal of Pediatrics 68, 215-221.

DUNNE, W. M. \& BUCKMIRE, F. L. A., JR (1985). Effects of divalent cations on the synthesis of alginic acid-like exopolysaccharide from mucoid Pseudomonas aeruginosa. Microbios 43, 193-216.

Evans, L. R. \& Linker, A. (1973). Production and characteristics of a slime polysaccharide of Pseudo- monas aeruginosa. Journal of Bacteriology 116, 914 924.

FILLIPOV, M. P. \& KoHN, R. (1974). Determination of composition of alginates by infra-red spectroscopic method. Chemicke zvesti 28, 817-819.

GACESA, P. (1987). Alginate-modifying enzymes: a proposed unified mechanism of action for the lyases and epimerases. FEBS Letters 212, 199-202.

GORIN, P. A. J. \& SPENCER, J. F. T. (1966). Exocellular alginic acid from Azotobacter vinelandii. Canadian Journal of Chemistry 44, 993-998.

Govan, J. R. W. (1975). Mucoid strains of Pseudomonas aeruginosa: the influence of culture medium on the stability of mucus production. Journal of Medical Microbiology 8, 513-522.

Govan, J. R. W., Fyfe, J. A. M. \& Jarman, T. R. (1981). Isolation of alginate-producing mutants of Pseudomonas fluorescens, Pseudomonas putida and Pseudomonas mendocina. Journal of General Microbiology 125, 217-220.

HaCKing, A. J., Taylor, I. W. F., Jarman, T. R. \& GovaN, J. R. W. (1983). Alginate biosynthesis by Pseudomonas mendocina. Journal of General Microbiology 129, 3473-3480.

Haug, A., Larsen, B. \& Smidsrod, O. (1966). A study of the constitution of alginic acid by partial acid hydrolysis. Acta chemica scandinavica 20, 183190.

Horan, N. J., Jarman, T. R. \& Dawes, E. A. (1981). Effects of carbon source and inorganic phosphate concentration on the production of alginic acid by a mutant of Azotobacter vinelandii and on the enzymes involved in its biosynthesis. Journal of General Microbiology 127, 185-191.

Horan, N. J., JaRman, T. R. \& Dawes, E. A. (1983). Studies of some enzymes of alginic acid biosynthesis in Azotobacter vinelandii grown in continuous culture. Journal of General Microbiology 129, 29852990.

Jarman, T. R., Deavin, L., Slocombe, S. \& RigheLATO, R. C. (1978). Investigation of the effect of environmental conditions on the rate of exopolysaccharide synthesis in Azotobacter vinelandii. Journal of General Microbiology 107, 59-64.

JAYASURIYA, G. C. N. (1955). The isolation and characteristics of an oxalate-decomposing organism. Journal of General Microbiology 12, 419-428.

Larsen, B., SkJak-Braek, G. \& Painter, T. (1986). Action pattern of mannuronan C-5-epimerase: generation of block-copolymeric structures in alginates by a multiple attack mechanism. Carbohydrate Research 146, 342-345.

LIN, T.-Y. \& HASSID, W. Z. (1966a). Isolation of guanosine diphosphate uronic acids from a marine brown alga, Fucus gardneri Silva. Journal of Biological Chemistry 241, 3282-3293.

LiN, T.-Y.\& HASsid, W. Z. (1966b). Pathway of alginic acid synthesis in the marine brown alga, Fucus 
gardneri Silva. Journal of Biological Chemistry 241 , 5284-5297.

LiNKER, A. \& JoNeS, R. S. (1966). A new polysaccharide resembling alginic acid isolated from Pseudomonads. Journal of Biological Chemistry 241, 38453851 .

McComb, E. A. \& McCready, R. M. (1957). Determination of acetyl in pectin and in acetylated carbohydrate polymers. Analytical Chemistry 29, 819-821.

Mian, F. A., Jarman, T. R. \& Righelato, R. C. (1978). Biosynthesis of exopolysaccharide by Pseudomonas aeruginosa. Journal of Bacteriology 134, 418422.

Piggott, N. H., Sutherland, I. W. \& Jarman, T. R. (1981). Enzymes involved in the biosynthesis of alginate by Pseudomonas aeruginosa. European Journal of Applied Microbiology and Biotechnology 13, 179-183.

PINDAR, D. F. \& BuCKe, C. (1975). The biosynthesis of alginic acid by Azotobacter vinelandii. Biochemical Journal 152, 617-622.
Sherbrock-Cox, V., Russell, N. J. \& Gacesa, P. (1984). The purification and chemical characterisation of the alginate present in extracellular material produced by mucoid strains of Pseudomonas aeruginosa. Carbohydrate Research 135, 147-154.

Singh, S., Hogan, S., Feingold, D. S. \& LaRSEN, B. (1987). Mucoid strains of Pseudomonas aeruginosa are devoid of mannuronan C-5 epimerase. Microbios 51, 7-13.

Skjak-Braek, G., Larsen, B. \& Grasdalen, H. (1985). The role of $O$-acetyl groups in the biosynthesis of alginate by Azotobacter vinelandii. Carbohydrate Research 145, 169-174.

SkJak-Braek, G., Grasdalen, H. \& Larsen, B. (1986). Monomer sequence and acetylation pattern in some bacterial alginates. Carbohydrate Research 154, 239-250.

Williams, A. G. \& Wimpenny, J. W. T. (1977). Exopolysaccharide production by Pseudomonas NCIB 11264 grown in batch culture. Journal of General Microbiology 102, 13-21. 